\title{
A C-glucoside benzoic acid derivative from the leaves of Peltophorum dubium
}

\author{
Marcus V. Bahia ${ }^{\mathrm{a}, \mathrm{b}}$, Jorge M. David ${ }^{\mathrm{a}, *}$, Larissa C. Rezende ${ }^{\mathrm{a}}$, Maria L.S. Guedes ${ }^{\mathrm{c}}$, Juceni P. David ${ }^{\mathrm{d}}$ \\ a Instituto de Química, Universidade Federal da Bahia, 40170290 Salvador, BA, Brazil

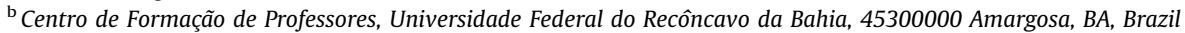 \\ ${ }^{\mathrm{c}}$ Instituto de Biologia, Universidade Federal da Bahia, 40170290 Salvador, BA, Brazil \\ ${ }^{\mathrm{d}}$ Faculdade de Farmácia, Universidade Federal da Bahia, 40170290 Salvador, BA, Brazil
}

A R T I C L E I N F O

\section{Article history:}

Received 22 March 2010

Received in revised form 4 July 2010

Accepted 9 July 2010

Available online 23 July 2010

\section{Keywords:}

Peltophorum dubium

Leguminosae

Benzoic acid C-glucoside

\begin{abstract}
A B S T R A C T
From the methanolic extract of the leaves of Peltophorum dubium Taub (Leguminosae) was isolated after successive chromatographic procedures a new C-glucoside benzoic acid derivative, $3 \alpha \mathrm{C}$-glucopyranosil4,5-dihydroxy-2-methoxy-benzoic acid. The structure of this compound was determined by 1D and 2D NMR and MS data analysis. The new compound showed moderate antioxidant activity in the assay and the auto-oxidation of $\beta$-carotene in a linolenic acid suspension method.
\end{abstract}

(c) 2010 Phytochemical Society of Europe. Published by Elsevier B.V. All rights reserved.

\section{Introduction}

The species Peltophorum dubium Taub is a tree belonging to the Leguminosae family (Caesalpinoideae). It occurs in Brazil from Bahia to Rio de Janeiro states, especially in the Atlantic forest complex, and also in other Brazilian regions as Minas Gerais, Goiás, Mato Grosso do Sul, Paraná and Sâo Paulo in deciduous forests, usually found in clay soils, deep and well common in riparian habitats (Lorenzi, 2000). In Brazil it is popularly known as "amendoim bravo", "faveiro", "pau vermelho", "angico" and "canela de veado". Its wood is employing in constructions, roof and the wood power is used for extraction of a red dye (da Silva, 2004). To date there is no records in literature regarding its chemical composition. Previously it was reported the antimicrobial activity (Salvat et al., 2004) and trypsin inhibition (Trancoso et al., 2003) of extracts of P. dubium.

However from $P$. africanum was previously isolated catechins and derivatives of gallic acid (Bam et al., 1988; Ferreira et al., 2005). The $\mathrm{MeOH}$ extract of this species showed inhibition of HIV-1 (Bessong et al., 2005), bactericidal (Samie et al., 2005) and antioxidant activities (Bizimenyera et al., 2007). Beside these, the ethanol extract of $P$. pterocarpum showed antimicrobial activity (Voravuthikunchai and Limsuwan, 2006).

This work describes the isolation of a new unusual C-glucoside benzoic acid derivative (Fig. 1) besides known triterpenes from the AcOEt extract of leaves of $P$. dubium.

\footnotetext{
* Corresponding author. Tel.: +55 7132836864; fax: +55 7132355166 E-mail address: jmdavid@ufba.br (J.M. David).
}

\section{Results and discussion}

Compound 1a was obtained as an amorphous white powder [m.p $198{ }^{\circ} \mathrm{C}$ (dec.)] and its structure was elucidated by spectrometric data analysis of the pure compound and the peracetylated derivative (1) $\mathbf{1 b}$. The ESIMS of 1a showed a negative pseudomolecular ion at $\mathrm{m} / \mathrm{z} 345.0834$ and, the combination with hydrogen and carbon counts obtained by ${ }^{1} \mathrm{H},{ }^{13} \mathrm{C}$ and DEPT NMR spectra permitted to propose the molecular formulae as $\mathrm{C}_{14} \mathrm{H}_{18} \mathrm{O}_{10}$ to this compound (requires 345.0822 ). The IR spectra permitted to identify presence of hydroxyl groups and conjugate carboxyl group $\left(v 1702 \mathrm{~cm}^{-1}\right.$ ). The analysis of ${ }^{1} \mathrm{HNMR}$ spectrum permitted to observe a singlet at $\delta 7.75$ of a pentasubstituted aromatic ring besides the presence of methoxyl group and hydrogens of sugar moiety (Table 1 ). The ${ }^{13}$ CNMR spectra, including DEPT experiments $\left(135^{\circ}\right.$ and $\left.90^{\circ}\right)$ permitted to corroborate with the previous statements and, moreover pointed the observed peak for the methoxyl group ( $\delta 60.4$ ) was indicative it was ortho-disubstituted. The comparison of oxymethine and oxymethylene carbons with the NMR data of sugars (Agrawal et al., 1989) permitted to identify the presence of glucose and, the anomeric carbon at $\delta 75.6$ was indicative of that $\mathbf{1}$ was a C-glucoside derivative of benzoic acid. The correlations of H-6 $(\delta 7.75)$ and carboxyl carbon ( $\delta$ 164.6), C-2 $(\delta 142.0)$ and C-4 $(\delta 152.7)$ observed in the HMBC spectra as well as the correlation of the peaks at $\delta 4.5$ (anomeric $\mathrm{H}$ ), methoxyl hydrogens and C-2 ( $\delta 142.0)$ permitted to locate the glucose at C-5. The $\Delta \delta$ of ${ }^{13} \mathrm{CNMR}$ signals of $\mathbf{1}$ and the acetylated derivative 1a corroborated with the presence of two vicinal hydroxyl groups at $\mathrm{C}-3$ and $\mathrm{C}-4$. Thus the new compound $\mathbf{1}$ could be identified as $3 \alpha$ C-glucopyranosil-4,5-dihydroxy-2-methoxy-benzoic acid. 


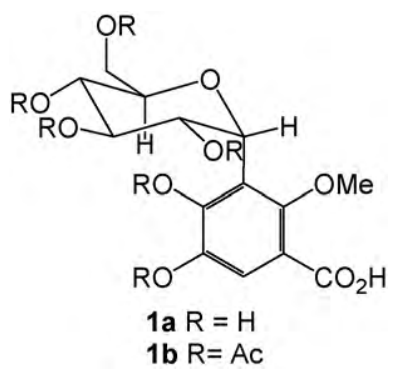

Fig. 1. New glucoside and derivative from Peltophorum dubium.

This work is the first report of $\mathbf{1}$, however, compounds with close structures, like norbergenin and bergenin were isolated from P. africanum (Mebe and Makuhunga, 1992) besides catechins esterified with gallic acid (Bam et al., 1988; Ferreira et al., 2005). Larreagenin-A was previously isolated from Larrea divaricata (Habermeeh and Christ, 1974) and Guaiacum officinale (Ahmad et al., 1984), two species of Zygophyllaceae family but this is the first occurrence in Leguminosae.

The extracts and the isolates were submitted to brine shrimp test employing Artemia salina nauplii and compound $\mathbf{1}$ was submitted to antioxidant tests (quenching of DPPH and inhibition of co-oxidation of $\beta$-carotene in a suspension of linolenic acid). The AcOEt extract showed $\mathrm{IC}_{50} 320 \mu \mathrm{g} / \mathrm{ml}$ in the BST indicating moderate activity. However, the hexane extract as well as the isolates were inactive $\left(\mathrm{IC}_{50}>500 \mu \mathrm{g} / \mathrm{ml}\right)$. The $\mathrm{IC}_{50}$ values $(\mu \mathrm{g} / \mathrm{ml})$ for $50 \%$ of DPPH scavenging radicals were calculated by linear extrapolation of values obtained from curve of antioxidant activity versus concentration. The results show that compound 1 $\left(\mathrm{IC}_{50}>120\right)$ did not present antioxidant activity when compared with gallic acid $\left(\mathrm{IC}_{50} 32.2\right)$ and quercetin $\left(\mathrm{IC}_{50} 11.2\right)$. However, in relation to inhibition of auto-oxidation of $\beta$-carotene method the data with $95 \%$ of confidence indicated that compound 1 $(\mathrm{AA}=10.52 ; 11.16 \%)$ presented the highest antioxidant activity than gallic acid $(A A=8.75 ; 9.2 \%)$ but lower than quercetin $(\mathrm{AA}=95.09 ; 100 \%)$.

\section{Experimental}

\subsection{Plant material}

The leaves of $P$. dubium Taub were collected at Ondina Campus, Universidade Federal da Bahia, Salvador, BA, Brazil. A voucher of A voucher is deposited at Herbarium Alexandre Leal da Costa of Instituto de Biologia da UFBA under number 69237.

\begin{tabular}{|c|c|c|}
\hline$C$ & 1 & $1 a$ \\
\hline 1 & 119.6 & 118.6 \\
\hline 2 & 142.0 & 141.3 \\
\hline 3 & 152.8 & 144.1 \\
\hline 4 & 152.7 & 144.1 \\
\hline 5 & 116.7 & 129.5 \\
\hline 6 & 111.1 & 124.0 \\
\hline 7 & 164.6 & 161.5 \\
\hline $1^{\prime}$ & 75.6 & 72.1 \\
\hline $2^{\prime}$ & 72.2 & 68.2 \\
\hline $3^{\prime}$ & 81.4 & 72.9 \\
\hline $4^{\prime}$ & 73.9 & 68.2 \\
\hline $5^{\prime}$ & 83.6 & 76.7 \\
\hline $6^{\prime}$ & 62.7 & 61.8 \\
\hline $\mathrm{OCH}_{3}$ & 60.4 & 61.4 \\
\hline
\end{tabular}

\subsection{Extraction and isolation}

The dried leaves $(1000 \mathrm{~g})$ of $P$. dubium were powdered and submitted to extraction with $\mathrm{MeOH}$ at room temperature. The solution obtained was partitioned between hexane furnished the hexanic extract $(2.0 \mathrm{~g})$. Sequentially, the $\mathrm{MeOH}$ phase was diluted with $\mathrm{H}_{2} \mathrm{O}$ and then submitted to liquid extraction with $\mathrm{CHCl}_{3}$ and EtOAc. The EtOAc extract $(1.2 \mathrm{~g})$ was chromatographed in a polyamide $6 \mathrm{CC}$ eluted with mixtures of $\mathrm{MeOH}: \mathrm{H}_{2} \mathrm{O}$. The fraction (300 mg) obtained after elution with $\mathrm{MeOH}: \mathrm{H}_{2} \mathrm{O}$ (1:4) was submitted to CC on Sephadex LH-20 employing $\mathrm{CHCl}_{3}: \mathrm{MeOH}(1: 4)$ mixtures. This procedure permitted to isolate 1 (62 mg). The Si gel CC of the hexane extract eluted with mixtures of hexane:ETOAc permitted to obtain a mixture (43.4 mg) of lupeol and larreagenin-A. These compounds were identified by direct comparison of MS and NMR spectral data $\left({ }^{1} \mathrm{H}\right.$, ${ }^{13} \mathrm{C}$ and DEPT) with the literature (Mahato and Kundu, 1994; Ahmad et al., 1984).

3 $\alpha$ C-Glucopyranosil-4,5-dihydroxy-2-methoxy-benzoic acid (1): IV $v_{\max }\left(\mathrm{cm}^{-1}\right): 3408,3090,1702,1613,1528,1071,1044 ;{ }^{1} \mathrm{H}$ NMR $\left(\mathrm{C}_{5} \mathrm{D}_{5} \mathrm{~N}, 300 \mathrm{MHz}\right): 7.75$ (s, $\left.1 \mathrm{H}, \mathrm{H}-2\right), \delta 4.50$ (d, J=4.5 Hz, H-1" $)$, 4.41-4.18 (m, 7H, H-1'-H6', glucose moiety), $\delta 3.98$ (s, 3H, OMe); ${ }^{13} \mathrm{C}$ NMR $\left(\mathrm{C}_{5} \mathrm{D}_{5} \mathrm{~N}, 75 \mathrm{MHz}\right)$ : Table 1 . HRESIMS $\mathrm{m} / \mathrm{z}: 345.0834$ $[\mathrm{M}-\mathrm{H}]^{+}$

Preparation of derivative: Compound $\mathbf{1}(20.0 \mathrm{mg})$ was added to a solution of pyridine $(0.5 \mathrm{ml})$, acetic anhydride $(0.5 \mathrm{ml})$ and dimethylaminepyridine (DMAP) for $24 \mathrm{~h}$ at room temperature and the peracetyl derivative (1a, $23 \mathrm{mg}$ ) was extracted with $\mathrm{CHCl}_{3}$. ${ }^{1} \mathrm{H}$ NMR $\left(\mathrm{C}_{5} \mathrm{D}_{5} \mathrm{~N}, 300 \mathrm{MHz}\right): \delta 7.76$ (s, 1H, H-2), 3.91 (s, 3H, OMe); ${ }^{13} \mathrm{C}$ NMR $\left(\mathrm{C}_{5} \mathrm{D}_{5} \mathrm{~N}, 75 \mathrm{MHz}\right)$ : Table 1.

\subsection{Brine shrimp and antioxidant tests}

The hexane and AcOEt extracts and isolated compounds were submitted to a Artemia salina lethality test (David et al., 2001). The antioxidant activities were evaluated by the ability of the new compound (1) and the gallic acid (Sigma) and quercetin (Sigma) scavenging the 1,2-diphenyl-2-picryl-hydrazyl (DPPH, Sigma) free radical and was carried out according to established protocol (Barreiros et al., 2004). The inhibition of the AA of the isolates was measured using the method of auto-oxidation of $\beta$-carotene (Merck) in a suspension of linolenic acid (Aldrich) (Barreiros et al., 2000). The results were compared to those from the commercial antioxidant gallic acid and BHT (Merck).

\section{Acknowledgments}

The authors are grateful to CNPq, CAPES, FAPESB and Instituto do Milênio do Semi-Árido (IMSEAR) for fellowship support and grants.

\section{References}

Ahmad, V.U., Bano, S., Bano, N., 1984. Phytochemistry 23, 2613.

Agrawal, P.K., Thakur, R.S., Bansal, M.C., Foo, L.Y., Markham, K.R., Porter, K.J., 1989. In: Agrawal, P.K. (Ed.), Carbon-13 NMR of Flavonoids. Elsevier, Amsterdam, p. 247.

Bam, M., Ferreira, D., Brandt, E.V., 1988. Phytochemistry 27, 3704.

Barreiros, A.L.B.S., David, J.M., David, J.P., 2004. Pharm. Biol. 42, 36.

Barreiros, A.L.B.S., David, J.P., de Queiroz, L.P., David, J.M., 2000. Phytochemistry 55, 805.

Bessong, P.O., Obi, C.L., Andréola, M.L., Rojas, L.B., Pouységu, L., Igumbor, E., Meyer, J.J.M., Quideau, S., Litvak, S., 2005. J. Ethnopharm. 99, 83.

Bizimenyera, E.S., Aderogba, M.A., Eloff, J.N., Swan, G.E., 2007. AJTCAM 4, 99.

da Silva, M.F., 2004. Nomes populares das Leguminosas do Brasil. Universidade Federal do Amazonas, Manaus, Brazil, p. 178.

David, J.P., da Silva, E.F., de Moura, D.L., Guedes, M.L.S., Assunção, R.J., David, J.M., 2001. Quim. Nova 24, 730.

Ferreira, D., Marais, J.P.J., Slade, D., 2005. Phytochemistry 66, 2216.

Habermeeh, G., Christ, B., 1974. Phytochemistry 13, 1293. 
Lorenzi, H., 2000. Árvores Brasileiras: Manual de Identificação e Cultivo de Plantas Arbóreas do Brasil. Nova Odessa, São Paulo.

Mahato, S.B., Kundu, A.P., 1994. Phytochemistry 37, 1517.

Mebe, P.P., Makuhunga, P., 1992. Phytochemistry 31, 3286.
Salvat, A., Antonacci, L., Fortunato, R.H., 2004. Phytomedicine 11, 230.

Samie, A., Obi, C.L., Bessong, P.O., Namrita, L., 2005. Afr. J. Biotechnol. 4, 1443.

Trancoso, M.F., Zolezzi, P.C., Hellman, U., 2003. Arch. Biochem. Biophys. 411, 93.

Voravuthikunchai, S.P., Limsuwan, S., 2006. J. Food Protect. 69, 2336. 